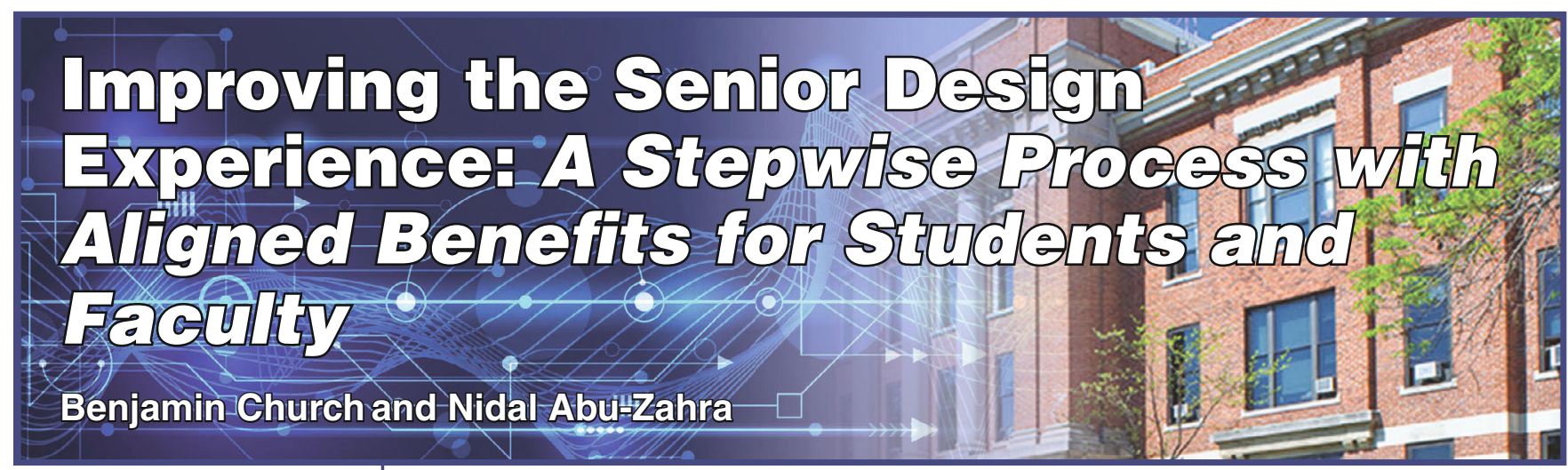

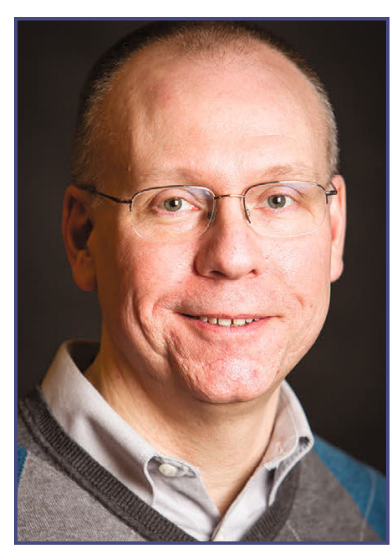

\section{Benjamin Church}

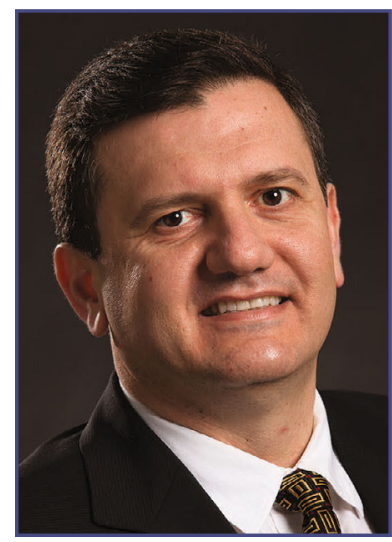

Nidal Abu-Zahra
Capstone or senior design courses provide students with an opportunity to combine aspects from a broad range of engineering courses into one individual or group design experience. These courses generally incorporate project-based experiences that challenge students to utilize knowledge and skills acquired throughout their university training. This provides a venue to evaluate ABET program outcomes and perform other continuous improvement activities. The design experience is also viewed as highly beneficial to the students ${ }^{1}$ and often seen as an important basis of evaluating students during industrial interviews ${ }^{2}$.

Ongoing and inevitable changes within a given program, inclusive of the curriculum, laboratory infrastructure, and faculty areas of expertise necessitate a periodic update to capstone course design. As ABET outcomes are often evaluated using the capstone course, changes to the course structure must also be aligned with broader program goals.

As an example, the Materials Science $\&$ Engineering (MSE) Department at the University of Wisconsin (UW)-Milwaukee has experienced a range of challenges and opportunities over the recent years, including a doubling in enrollment, increased enrollment in service courses, a changing budget model at the university level, and changes in department faculty. These developments have provided the inputs for departmental strategic planning and aligning aspects of teaching, research, and service to provide greater benefits to students, faculty, and other stakeholders.

The MSE department at UW-Milwaukee has a mission to provide our graduates with a well-rounded engineering education with specific emphasis on materials science and engineering. The mission of the department is informed by directions and feedback from our Industrial Advisor Board (IAB), the mission of the College of Engineering and the university, and with consideration to changes in ABET accreditation processes.

Based on the department mission, the strategic plan embodies the department's goals and activities and creates a method by which the program can be managed. Assessments and evaluations are a key aspect of this management plan and include significant input from current students and recent graduates. This establishes a continuous loop between the strategic plan, program management, and program assessment. At the center of the loop is the overarching goal of sustainability and growth of the program, the faculty/staff, and the department.

This process provides the context for how the senior design course at UWMilwaukee has been modified over the past several years, resulting in a course better aligned with student interests, program objectives, and faculty interests.

\section{Incremental Changes}

Changes to the MSE senior design course were implemented over three years, as summarized in Table 1. Up until the 2014-15 academic year, the senior design course consisted of a one-semester fourcredit course offered in the spring. One instructor managed the course, although all faculty were invited to participate in the final project presentations and evaluations. Based on enrollment and the success in soliciting industrial projects, the sole instructor could be responsible for mentoring four or five industrially focused projects during the semester. 
Student feedback indicated that the course often created more frustration than benefit due to the tight timing. Students commented that a four-month window was insufficient to both plan and execute a project, even when project teams, goals, and other aspects were determined early in the process. Faculty feedback highlighted the pressures of soliciting and developing industry-based projects singlehandedly and the demands of mentoring multiple teams.

Changes to the capstone course were needed to improve course outcomes and align resource requirements with department resources. The following characteristics were identified as being integral to an improved senior design experience:

- Greater calendar time for students to scope projects and engage in project planning

- Increased faculty participation

- Participation of IAB for project vetting and assessment

- Reduced dependence on MSE department funding

- Incorporation of a continuous improvement model

- Increased diversity of project topics

- Expanded industry engagement

- Alignment with MSE department strategic goals

- Multidisciplinary and inclusive teams

- Greater inclusion of ABET outcomes

The initial change in 2015 split the original four-credit, one-semester course into a one-credit fall course followed by a three-credit spring course. The fall semester course focused on project planning aspects such as teambuilding, project planning, mentoring on communications and ethics, and identification of specific project goals. At the same time, the course was transitioned to a new instructor who mentored all teams.

The fall one-credit course was structured to meet once per week for activities to a) assist students with developing skills necessary for success in a team project and b) provide assessment opportunities for ABET outcome tracking.

\begin{tabular}{|c|c|c|c|c|c|}
\hline Year & $\begin{array}{c}\text { Semester } I \\
\text { Credits }\end{array}$ & $\begin{array}{c}\text { Project } \\
\text { Type }\end{array}$ & $\begin{array}{c}\text { Project } \\
\text { Developer }\end{array}$ & $\begin{array}{c}\text { Project } \\
\text { Mentor* }\end{array}$ & $\begin{array}{c}\text { ABET } \\
\text { Evaluation }\end{array}$ \\
\hline $\begin{array}{c}\text { Pre- } \\
2015\end{array}$ & $\begin{array}{c}\text { Spring, } \\
4 \text { Credit }\end{array}$ & Industrial & Instructor & Instructor & Instructor \\
\hline 2015 & $\begin{array}{c}1 \text { Credit Fall } \\
3 \text { Credit Spring }\end{array}$ & Industrial & Instructor & Instructor & Instructor \\
\hline 2016 & $\begin{array}{c}1 \text { Credit Fall } \\
3 \text { Credit Spring }\end{array}$ & Industrial & $\begin{array}{c}\text { Faculty } \\
\text { Coordinator }\end{array}$ & $\begin{array}{c}\text { Individual } \\
\text { Faculty }\end{array}$ & $\begin{array}{c}\text { Faculty } \\
\text { Coordinator }\end{array}$ \\
\hline 2017 & $\begin{array}{c}1 \text { Credit Fall } \\
\text { Credit Spring }\end{array}$ & Industrial & $\begin{array}{c}\text { Individual } \\
\text { Faculty }\end{array}$ & $\begin{array}{c}\text { Individual } \\
\text { Faculty }\end{array}$ & All Faculty \\
\hline Future & $\begin{array}{c}1 \text { Credit Fall } \\
3 \text { Credit Spring }\end{array}$ & $\begin{array}{c}\text { Academic or } \\
\text { Industrial }\end{array}$ & $\begin{array}{c}\text { Individual } \\
\text { Faculty }\end{array}$ & $\begin{array}{c}\text { Individual } \\
\text { Faculty }\end{array}$ & All Faculty \\
\hline
\end{tabular}

Table 1. Matrix of changes incorporated to the senior design program since 2015. Stepwise changes are highlighted.
These activities included discussions or assignments related to teambuilding, identifying resources, laboratory safety, ethics in engineering, professional communication, time management, and conflict resolution. The major deliverable of the fall semester course was a group proposal that outlined the project objectives, proposed methodologies, and expected outcomes.

The spring three-credit course was structured to maximize team project work. Student-faculty-industry interactions were intended to simulate general industrial work environments ${ }^{3}$. The major deliverables from the threecredit spring semester were final project reports delivered to the industry mentors and final presentations made to an audience of faculty, undergraduates, graduate students, IAB members, and other guests.

Student feedback from the 2015 year showed that the time pressures were alleviated by having project goals established in the fall semester, although feedback regarding the content of the fall semester was largely negative. Activities from the fall that did not directly align with the project were generally regarded as irrelevant and of minimal benefit.

The second round of changes distributed the faculty mentorship role so that each team was mentored by a different faculty. Reasons for this change included the ability to align project topics with faculty expertise. The main instructor of the course took on a "faculty coordinator" role and continued to deploy the same content in the initial fall semester, with modest tweaks based on prior student feedback. Faculty mentors did not participate in the general assessment of individual assignments, but did engage in final project assessments much to the same degree as in the past.

Student feedback from the change in faculty mentorship was largely neutral. Several students commented positively on having a good alignment between project topics and the expertise area of the faculty mentor. Faculty commented that the process allowed additional collaboration and relationship building with the industry participants that they would have otherwise not experienced.

The 2017 academic year saw additional changes focused on continued distribution of project responsibilities away from the main coordinator to the faculty mentoring each individual project. The solicitation and development of the projects were put in the hands of individual faculty mentors, although the coordinator maintained some input on how the projects were scoped. The grading for the spring semester three-credit course included a range of metrics such as peer evaluations, faculty mentor scoring of bi-weekly status update memos, and final project presentations/reports that were graded by multiple faculty.

Students were less aware of changes in terms of project origanization than they were 
aware of changes to grading responsibilities for bi-weekly updates. Final project grading by multiple faculty other than the team mentor was perceived as a positive change by the students. There was increased diversity in technical depth and the degree to which the concept of design ${ }^{4}$ was incorporated into each project relative to years when all projects were scoped by one person.

Additional changes are being adopted for the 2018-19 academic year, focusing on faculty mentoring and project development. A process for project review and approval is being developed where the project scope is outlined by the faculty and industry mentors and then reviewed (i.e. graded) using a whitepaper on design in materials engineering ${ }^{4}$ as a basis for approval.

Table 2 summarizes changes to the senior design course, along with brief descriptions of the benefits to the individual faculty and to the program/student. The sustainability and growth of the department and program are enhanced by enacting changes that benefit both students and faculty.

\section{Future Challenges and Opportunities}

Historically, UW-Milwaukee does not require a financial donation or fee from industry participants for senior design projects. There are clear benefits for the program to incorporate a fee, as the execution of a project always incurs expenses with things such as consumables and access to instrumentation. With continued budgetary pressures, it may become necessary to implement some level of fee, although industry mentors have indicated that fees charged by other institutions fall at levels above their immediate budgetary control and become barriers to their participation.

The undergraduate population in MSE at UW-Milwaukee includes a sizable percentage of students who work in industrial positions either full-time or part-time while enrolled in classes. During the senior year, this can create additional pressures on course scheduling and the ability for some students to have the time necessary to be fully contributing members of a student design team. Opportunities may exist to integrate internship/co-op positions into the senior design process as has been done in other ABET programs ${ }^{5}$, although this approach certainly is not without concerns ${ }^{6}$. Additional flexibility could be incorporated by shifting the one-credit fall semester course to an online format.

The industry focus of the projects may be expanded to include projects of a more academic nature. For students seeking an advanced degree, a capstone project that has more focus on research merit may provide a better platform. This expansion of project focus may also consider a larger incorporation of entrepreneurial activities ${ }^{7}$ and a greater consideration to the topic of sustainability .

Future changes to the course are inevitable and will be considered from the perspective of combining continuous improvement of the student educational experience with the broader needs of the faculty and department. By considering potential changes to the course from multiple perspectives that emphasize the student experience, but are informed by the strategic mission of the program, changes can be analyzed to ensure continued growth and future sustainability.

\begin{tabular}{|l|c|c|}
\hline $\begin{array}{l}\text { Change to the } \\
\text { Penior Design }\end{array}$ & Faculty Perspective & $\begin{array}{c}\text { Program/Student } \\
\text { Perspective }\end{array}$ \\
\hline $\begin{array}{l}\text { Transition from } \\
\text { single semester to } \\
\text { two-semester } \\
\text { sequence }\end{array}$ & $\begin{array}{c}\text { Ability to include additional } \\
\text { content/activities to } \\
\text { broaden ABET and other } \\
\text { assessments }\end{array}$ & $\begin{array}{c}\text { Increased calendar time to } \\
\text { better plan project goals } \\
\text { and objectives; decreased } \\
\text { anxiety }\end{array}$ \\
\hline $\begin{array}{l}\text { Team mentorship } \\
\text { distributed among } \\
\text { participating faculty }\end{array}$ & $\begin{array}{c}\text { Avoids potentially } \\
\text { burdensome workload on } \\
\text { single faculty that could } \\
\text { create burnout or lead to } \\
\text { poor project mentoring }\end{array}$ & $\begin{array}{c}\text { Increased competition } \\
\text { between teams; better } \\
\text { access to faculty with } \\
\text { expertise relevant to } \\
\text { project }\end{array}$ \\
\hline $\begin{array}{l}\text { Projects developed } \\
\text { by participating } \\
\text { faculty }\end{array}$ & $\begin{array}{c}\text { Ability for faculty to } \\
\text { engage with industries of } \\
\text { specific interest; build } \\
\text { better relations with key } \\
\text { industry contacts; } \\
\text { alignment with teaching } \\
\text { and research activities }\end{array}$ & $\begin{array}{c}\text { Heightened support for } \\
\text { project success from } \\
\text { faculty mentors; better } \\
\text { alignment with resources } \\
\text { (e.g. research equipment, } \\
\text { grad student know-how); } \\
\text { increase engagement from } \\
\text { faculty mentors }\end{array}$ \\
\hline $\begin{array}{l}\text { Assessment } \\
\text { responsibility } \\
\text { partially distributed } \\
\text { among participating } \\
\text { faculty }\end{array}$ & $\begin{array}{c}\text { Direct feedback to student } \\
\text { in team for low-stakes } \\
\text { deliverables; scoring by } \\
\text { other faculty for final } \\
\text { submissions enhance peer } \\
\text { accountability }\end{array}$ & $\begin{array}{c}\text { Faculty mentor guidance } \\
\text { on major deliverables is } \\
\text { perceived as advice and } \\
\text { less as a guide to } \\
\text { obtaining }\end{array}$ \\
a high score
\end{tabular}

Table 2. Links between senior design program changes and benefits realized by faculty and students.

\section{Endnotes}

1. R. W. Heckel, W. W. Milligan, C. L. Nassaralla, J. Pilling, and M. R. Plichta, in Science and Technology of Polymers and Advanced Materials (Springer, Boston, MA, 1998), pp. 859-867.

2. EngineerJobs Magazine (2015).

3. T. H. DeAgostino, V. M. Jovanovic, and M. B. Thomas, 2014 ASEE Annual Conference \& Exposition 24.1083.1 (2014).

4. "White Paper on "Design" in Ceramics, Materials, Metallurgical and Similarly Named Engineering Programs" (TMS, 2006), https://www.tms.org/portal/ downloads/profdev/abet/WhitePaperonDesign02252006. PDF. Accessed 04 May 2018.

5. R. Fries, B. Cross, and S. Morgan, 2010 ASEE Annual Conference \& Exposition 15.159.1 (2010).

6. J. Goldberg, IEEE Pulse 7, 50 (2016).

7. A. H. Hoffman, in 2017 IEEE Frontiers in Education Conference (FIE) (2017), pp. 1-5.

8. R. LeSar, K. C. Chen, and D. Apelian, MRS Bulletin 37, 449 (2012).

\section{Benjamin Church is associate professor of materials science and engineering and} Nidal Abu-Zahra is associate professor and department chair of materials science and engineering at the University of WisconsinMilwaukee. 